\title{
IMPLICATION OF PRODUCT BRANDING ON CUSTOMER'S PATRONAGE IN THE NIGERIAN CONSUMER GOODS INDUSTRY
}

\author{
Matthew Adekunle Abioro \\ Department of Business Administration, Federal University of Agriculture, Abeokuta, Nigeria \\ abioroma@funaab.edu.ng \\ Samuel Abimbola Odunlami \\ Department of Business Administration, Augustine University, Ilara Epe, Lagos State, Nigeria \\ samuel.odunlami@augustineuniversity.edu.ng
}

\begin{abstract}
Product branding is said to be a veritable tool that can be adopted in achieving customer patronage in the highly competitive market. Hence, this study assesses the implication of product branding on customer's patronage. The specific objectives of this study were to evaluate the effects of brand perception, service quality and customer relationship management on customer's patronage. A survey research design was used for the study, with a structured questionnaire administered to collect data from the firms' customers. The inferential statistical tool of regression analysis was adopted to analyze the formulated hypotheses. Findings revealed that brand perception has a significant effect on customer patronage $\left(R^{2}=0.308, P=0.000\right)$, it also shows a significant effect of service quality $\left(\mathrm{R}^{2}=0.623, \mathrm{P}=0.000\right)$ on customer patronage, and a significant effect of customer relationship management $\left(R^{2}=0.585, P=0.000\right)$ on customer patronage. The study concluded that product branding if properly managed can influence customers patronage, and also having the ability to increase the customers base and profitability of the firm. It was therefore recommended that firms should give proper consideration to issues of customer relationship management; as well as enhancing the product service experience of customers so as to improve the perception of the brand in the mind of customers to foster brand loyalty.
\end{abstract}

Keywords: Brand Perception, Service Quality, Product Branding, Customer Service, Customer Patronage.

DOI: https://doi.org/10.24818/beman/2021.11.2-01

\section{INTRODUCTION}

Due to high level of competition that exist in today's dynamic business environment and the changing economic conditions, every organisation is aiming at attracting various customer's patronage by adopting differentiation strategy, so as to remain relevant and for business survival (Mohebbi, 2014). This increased competition has made the concept of branding an important phenomenon. Consumers' perception about brands has been an essential determinant for business in the long run. Thus, creating a robust brand perception is now of a major significance for business operations and existence. Product 
branding is one of the most contemporary tactics adopted to ensure not only the company's business success or loyalty of customers but also longevity in terms of customers and company relations. Logically, a customer that is loyal to a brand feel less risk and greater confidence in the company. Kotler (1996) opined that attracting new customers is more tedious and stressful than retaining existing customers. The success of marketing can therefore be achieved based on the quantity of customers that are profitable to an organization and their obvious impact on business sales and profitability.

According to Akbar \& Parvez (2009), brand is an image that customers have in their mind. Murphy (1990) also asserted that it is a special or unique characteristic that have been developed over time to differentiate actual company's products from that of competitors. Product branding is a symbol of identity that differentiates a product from a pool of others. It entails the practise of developing a matchless name and identity for a product or business and ensures brand credibility thereby creating customers' loyalty. Product branding therefore automatically develops a personality and a reputation for a product or business.

Companies abound around the globe with strong identity of brands in the market and often tend to possess a competitive advantage over those with weaker brands or those with no brand identity at all. Some customers get more connected to firms owning strong brand identities and not essentially the benefits they stand to gain from the brands. Marketers differentiate mental and experimental aspects to a brand. The experimental aspect which consists of an accumulation or sum of contacts with the brand is known as brand experience while the psychological or mental aspect which is the symbolic picture painted in the thoughts of people consisting of all information and anticipations from the product. Consumer perceives brand as a vital fragment of products and branding can bring about value addition to a particular product as customers bestow meanings to it and pursue to establish relationship with the product brand. Although branding is more than just symbols and names, they are important elements in how the firm relates with its customers.

In practice, customers patronage is explained as a commitment to continue purchasing a preferred product or service consistently and recommending to colleagues. A study of Mcllroy \& Barnett (2000) argued that this relationship will continue to exist in as much customers feel that they are receiving better than what is obtainable from rival suppliers. Business can experience increase in their profit level, rapid business growth and have edge over competitors when there is continuous repurchase from their customers (Singh \& Khan, 2012; Farquhar, 2003). It has been identified that customers have a life cycle, and it should be attained, maintained, and nurtured to move on the value ranking from first time consumers to become partners (Ang \& Buttle, 2006). Customer's patronage plays a key role when it comes to organizations' sustainability and profitability, respectively. It cost more than double to gain new 


\section{Abioro, M.A., Odunlami, S.A. \\ IMPLICATION OF PRODUCT BRANDING ON CUSTOMER'S PATRONAGE IN THE NIGERIAN CONSUMER \\ GOODS INDUSTRY}

customers or clients than it would cost to retain existing clients. In a situation where there are two competing companies having equal returns on sales, the company which sells more to same customers will have significantly higher profits compared to the ones that sell to random one-off purchase customers.

The concept of product branding is not a new word in academia as different studies by (Mahdi, 2017; Negin et al., 2013; Hossein \& Fateme, 2013; Oladele et al., 2015; Borishade et al., 2015; Olawepo \& Ibojo, 2015) have been carried out to investigate the effect of brands dimensions on customers' patronage and loyalty. Despite previous studies on this subject matter and related ones, there seems to be some level of contradictions as to whether product branding increases or worsen or even has any effect at all on customer's patronage. It is against this backdrop, that this study aims at achieving the specific objectives of evaluating the implication of product branding variables such as (brand perception, service quality and customer relationship management) vis-a-vis customers patronage using $\mathrm{PZ}$ Cussons PIc, Nigeria as a study area.

\section{LITERATURE REVIEW}

\subsection{Conceptual Clarifications: Product branding concept}

Deciding a specific brand name for a product being introduced into the market has been identified as one of the crucial steps in branding strategy. Hence, professional marketers must possess a distinctive skill to innovate, protect, create, maintain and enhance brands. A brand is said to be a word, mark, symbol, device used to identify some product or service. The American Marketing Association (AMA) explains a brand as 'a term, name, symbol, sign, or design, deliberately used to recognize the product of one seller or group of sellers and to differentiate them from others in the same line of business (competitors). Oladele et al. (2015) explained that product branding constituted an essential aspect of projecting a firm's brand's image. Branding of products is not new in the marketing world. It all started with brand names which later developed to entail an experience with a company's products or services. An example is Coca-Cola which has included bottles of different shapes and varieties to satisfy different consumer preference. Also, according to Ahmed, Parmar \& Amin (2014), branding is described as a whole package that becomes an ultimate selling proposition, which stimulates impulse buying behaviour. The market is very competitive and saturated with similar product and so in order to ensure that a product stands out, companies begin to ascribe some properties of identification such as name, logo, colour and other features to give the products a position, a voice and a distinctive personality. This is known as product branding. Anholt (2010) opined that the role of branding in most phases of life can 
include cultural, political, social, unofficial, official, public and private. However, the following component of product branding for this study were explained below.

\subsubsection{Brand Perception}

Perception, on its own could be defined as a mental impression of something ensuing from its interpretation by the senses. Coupled with the knowledge of what a brand is, brand perception is the way consumer interprets a brand built on sensory information obtained during interactions with it (Hossein \& Fateme 2013). In simpler terms, it is the way consumers feel, think, and react to a brand based on their personal experiences with it, which can be positive, negative or neutral. Having adequate knowledge of what forms brand perception is highly crucial for every business. In order to improve the perception of a brand, business owners need to listen to customers' views and opinions. When a consumer sees or hears a brand name and is vigilant about the brand, something psychological happens, whether the individual is aware of it or not. An initial reaction which involves feelings and thoughts towards the brand is almost taking place and this result from what the marketing world translates into brand perception (Olawepo \& Ibojo 2015). The followings are some of the variables of brand perception that are well known: quality, value, visual, senses, personality, reputation, status and culture. Based on this assertion, the first part of the hypothesis is formulated; $\mathrm{H}_{0}$ : Brand perception has no significant effect on customer's patronage.

\subsubsection{Service quality}

Bhandari \& Sharma (2009) explained service quality as the provision of excellent and superior service relative to meet customer expectations. Krey et al., (2014) perceive that the comparative significance of service quality dimensions to customers differs and depends on their culture and resource allocation on different scopes of service quality. Saha et al., (2014) acknowledged service quality as the most important goal of service industries going by studies that connect customer satisfaction and good service quality together. It was equally observed that the enlargement of the quality of services that firms provide in order to maintain customer satisfaction as the substitute to retaining and increasing the customer base or sustaining customer patronage. They argue that it is crucial to organizations going concern since no organization will remain in business when none of their customers is loyal to the firm. Accordingly, the second hypothesis is formulated; Ho: Service quality has no significant effect on customer's patronage. 


\section{Abioro, M.A., Odunlami, S.A. \\ IMPLICATION OF PRODUCT BRANDING ON CUSTOMER'S PATRONAGE IN THE NIGERIAN CONSUMER \\ GOODS INDUSTRY}

\subsubsection{Customer Relationship Management}

Lately, relationship management has become a very strong and common concept in marketing literature, and it is not a strange or new thing. In business world, customer relationship management has become a vital tool that can be used in marketing in ensuring customers' patronage. In a competitive environment where business struggles to have edge over others, customer relationship management can be a rescue savior. According to Mahdi (2017) relationship management is a conscious work or effort to establish, develop or liquidate relations in ways that could create value for both parties involved. It is a strategy that can be deployed by manager to achieve continuous relationship with customer through any means that will not hurt the customer. It is usually done by having influence on the customer rather than through force. Hyosung \& Bryan (2008) see it as a way managers can put themselves in customers' shoe and think like them as they will be the one to evaluate the firm and market it to others through recommendation and word of mouth. It is a way of establishing concrete relationship with customers to secure their patronage and loyalty. The above preposition will lead to the formulation of the third hypothesis; $\mathbf{H}_{\mathrm{o}}$ : Customer relationship management has no significant effect on customer's patronage.

\subsubsection{Concept of Customer Patronage}

The whole essence of setting up a business is to create customer vis-a-vis customer satisfaction (Dadras 2016). The result of customers' satisfaction is more customers' patronage, and this happens when the customer is satisfied with the company's brand. Krey et al., (2014) opined that company's effort to satisfy their customers helps in building consumer patronage to a brand, product, or service. Hence, the significance of both customers and customer patronage to a brand cannot be over emphasized.

A study by Adiele et al., (2015) explain customer patronage as the supports an organization enjoy or benefited from the customers. It can also be classified as respondent's rating for company sales volume, profit margins and customers retention level. According to Oliver (1999), customer patronage involves having deep commitment towards repurchasing a firm's products at the expense of what others in the same line of trade (competitors) has to offer. A study by Kotler \& Keller (2011); Dadras (2016), further examined factors that influences the level of customer's patronage. These factors include economic situation, competitors, social and psychological factors, product or services attributes, and marketing mix programs. Therefore, customer patronage is an essential condition for a firm to maintain business continuity, basis for stability and market share. This concept has different dimensions, in that customers that patronize a product are those who refuse the preferential price provided by a competitor 
Abioro, M.A., Odunlami, S.A.

of the company and continue to buy the product or service of the company and promote it free of charge to others by obligation.

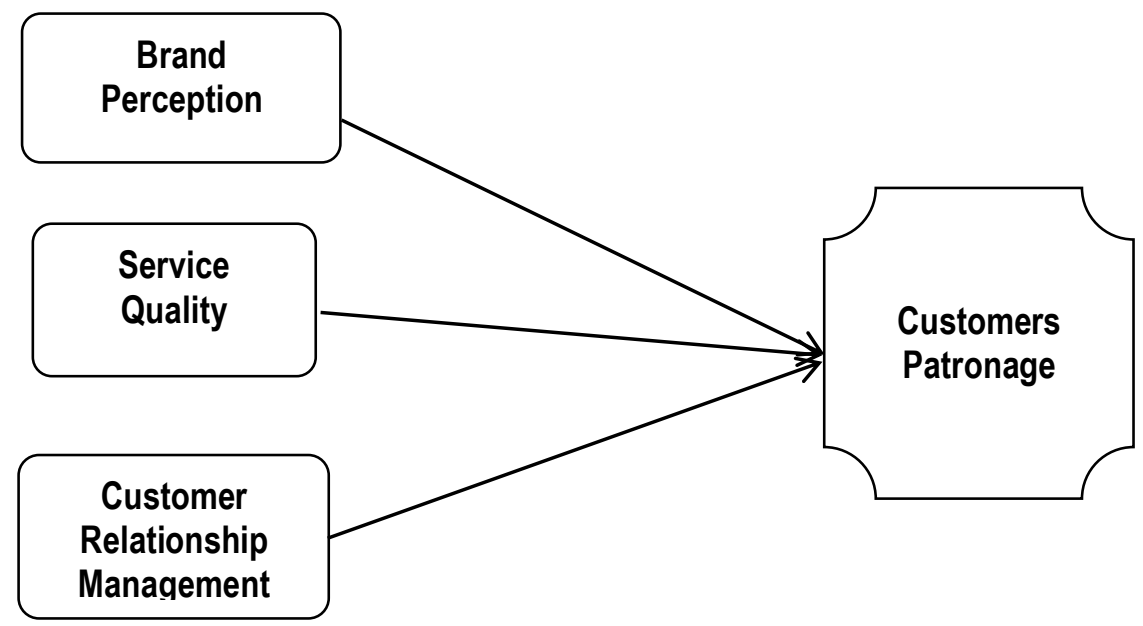

Figure 1: Conceptual Model

Source: By the Author

\subsection{Theoretical Review}

There are different theories that were propounded by different scholars that have capacity to paddle the objective of this study. However, the two theories that best fit for this study are: brand relationship theory and theory of reasoned actions. The brand relationship theory also known as consumer-brand relationship, is that relationship that consumers have, feel and think about a product or business brand. According to Fornell (2016) the theory is a new paradigm that is concentrated on relationship that was established between brands and consumers, a situation whereby a relationship is formed physically in the minds of buyers. Gummesson (2015) pointed out that there is an existing relationship among humans and therefore, customers view brand relationship in their own singular perceptions that brand relationship and relational value are personalized in the minds of the consumers. The varying customer's opinion of brand value, brand meaning, and their experiences makes them generate individual relationships in their mind. Lindberg (2015) posits that customers seem to individually create the brand via their communications through numerous contexts.

On the other hand, theory of reasoned actions has been classifying as a theory that can be used to expound human behaviors (Poon, 2008). The theory posits that the precursors of purchase behavior are approaches towards the purchasing and subjective standard (Cheah \& Phau, 2011). If the history of purchasing behavior is united to envisage and quantify brand loyalty, the prediction and quantification of 


\section{Abioro, M.A., Odunlami, S.A. \\ IMPLICATION OF PRODUCT BRANDING ON CUSTOMER'S PATRONAGE IN THE NIGERIAN CONSUMER \\ GOODS INDUSTRY}

brand loyalty will be more established over time and accurate. Reasoned action theory (TRA) has been established to have full knowledge of the relationships that exist between intentions, attitudes, and behaviors (Azjen \& Fishbein 2008).

\subsection{Empirical Review}

There has been divergent views and opinions among scholars and practitioners in the field of business and marketing management as regard the positive vis-a-vis the negative implications of product branding on customer patronage. A study by Farooq et al., (2015) on customers perception of Chinese fast food restaurant service quality and its effect on customer patronage. Findings from the 205 respondents revealed that service quality has a positive significant effect on customer patronage. An empirical research by Mohebbi (2014) on evaluation of the determinants of customer patronage in fast food industry in Pakistan. The result of correlation and multiple regression show that factors like price, service quality and environment are significant determinants of customer patronage. Zekiri \& Hasani (2015) work on the impact of branding on customer patronage revealed a positive relationship between the independent and dependent variables.

The study of product branding (packaging) as a predictive factor of customer patronage in Ado-Ekiti, Nigeria was conducted by Oladele et al., (2015). The result of the analysis revealed a positive relationship among variables of branding (quality, quantity and color) and customer patronage. Olawepo \& Ibojo (2015) further examined the relationship between branding and consumer purchase intention; a study of Nestle Nigeria Plc. The result establishes a positive nexus among the identified variables. In addition, Borishade et al., (2015) empirical study of branding on consumer purchasing decision in a food and beverages firm in Nigeria. The findings of the result revealed that branding plays a significant role in the purchase decision of the customer. Nifforushan \& Haeri (2015) further assess the role of product branding on customers perception. The result showed that service quality and customer relationship management had a significant influence in determining customers satisfaction (patronage).

\section{METHODOLOGY}

The focus of this study was on fast moving consumer goods industry (FMCG) in Lagos, Nigeria. A descriptive survey research design was adopted for the study to elicit data among the customers of $P Z$ Cussons Plc in Lagos. Primary data were collected through a structured questionnaire to evaluate the implications of product branding on customers patronage in the Nigerian manufacturing firms. A total of two hundred and ten (210) questionnaire was administered by the researcher and completed by respondents of which 185 are considered to be valid and usable for the analysis. However, the 5-point Likert scale ranging from strongly agree-strongly disagree was equally used to elicit appropriate 
Abioro, M.A., Odunlami, S.A.

responses, where $5=$ Strongly agree, $4=$ Agree, $3=$ Undecided, $2=$ Disagree, and $1=$ Strongly disagree. Cronbach Alpha reliability of the instrument is above cut off point of 0.7. Both descriptive and inferential statistics were used to analyse the data generated. A descriptive tool was used to analyse the demographical characteristics of the respondents, while regression analysis techniques was employed to test the formulated hypotheses.

\section{Model Specifications}

For the purpose of this study the model below were used

The implicit form of equation for the model is specified in equation;

$Y=f(x)$

While the explicit form of the equation for the model is specified in equation;

$X=f\left(x_{1}, x_{2}, x_{3}, \ldots . . n\right)$

Therefore;

$Y=\beta_{0}+\beta x_{1}+\beta x_{2}+\beta x_{3}+\varepsilon$

$C P=\beta_{0}+\beta(B P)_{1}+\beta(Q S)_{2}+\beta(C R M)_{3}+\varepsilon$

Where: $\mathbf{Y}=$ Customer Patronage (CP)

$$
\begin{aligned}
& \mathbf{x}_{1}=\text { Brand Perception (BP) } \\
& \mathbf{x}_{2}=\text { Service Quality (SQ) } \\
& \mathbf{x}_{3}=\text { Customer Relationship Management (CRM) } \\
& \boldsymbol{\varepsilon}=\text { Error Term Estimate } \\
& \beta=\text { unknown population parameter }
\end{aligned}
$$

\section{ANALYSIS AND RESULT}

TABLE 1. RESEARCH SAMPLE

\begin{tabular}{|c|c|c|}
\hline Questionnaire & Respondents & Percentage (\%) \\
\hline Returned & 185 & 88.1 \\
\hline Not Returned & 25 & 11.9 \\
\hline Total & $\mathbf{2 1 0}$ & $\mathbf{1 0 0}$ \\
\hline
\end{tabular}

Source: Field Survey, 2021

A total number of 210 structured questionnaires were distributed among respondents, out of which 185 were appropriately filled and returned. This implies that $88.1 \%$ of questions administered were retrieved. This means that the number of returned questionnaires is good enough to make valid conclusions. 


\subsection{Test of Hypotheses}

\section{Hypothesis One}

$\mathrm{H}_{0}$ : Brand perception has no significant effect on customer patronage.

TABLE 2: RESULT OF REGRESSION ANALYSIS

\begin{tabular}{|c|c|c|c|c|c|c|c|}
\hline \multirow[t]{2}{*}{ Model } & \multicolumn{2}{|c|}{$\begin{array}{l}\text { Unstandardized } \\
\text { Coefficients }\end{array}$} & $\begin{array}{l}\text { Standardized } \\
\text { Coefficients }\end{array}$ & \multirow[t]{3}{*}{$R^{2}$} & \multirow[t]{3}{*}{$\begin{array}{l}\text { Adjusted } \\
\mathrm{R}^{2}\end{array}$} & \multirow[t]{2}{*}{$\mathrm{t}$} & \multirow[t]{2}{*}{ Sig. } \\
\hline & B & Std. Error & Beta $(\mathrm{R})$ & & & & \\
\hline \multirow{2}{*}{$\begin{array}{l}\text { (Constant) } \\
\text { Brand } \\
\text { Perception }\end{array}$} & 3.639 & .734 & & & & 4.959 & .000 \\
\hline & .618 & .069 & .555 & .308 & .304 & 9.016 & .000 \\
\hline
\end{tabular}

Source: Authors' computation on SPSS (2021)

\section{Interpretation}

Table 2 revealed that $R^{2}=0.308$, Adjusted $R^{2}=0.304, P<0.05 . R^{2}$ measures the percentage of variation in the dependent variable caused by variation in the independent variable. It implies that $30.8 \%$ of the variation in customer patronage was caused by brand perception. The balance is accounted for by the stochastic error. However, $30.8 \%$ is substantial enough in terms of measuring the goodness of fit of the model. This is an indication that brand perception has a significant effect on customers patronage. Also, evaluating the contributions of the independent variable to the prediction of the dependent variable in the table, it shows a coefficient value of 0.618 with a t-statistic of 9.016 and probability value of 0.000 . With probability value less than the chosen 0.05 critical value, it implies that the independent variable (brand perception) has a statistically significant effect on the dependent variable (customer patronage). This significant effect is also positive, judging from the positive sign of the coefficient value. In summary, the findings revealed that the null hypothesis is rejected in favor of the alternative hypothesis that brand perception has a significant effect on customer patronage.

\section{Hypothesis Two:}

$H_{0}$ : Service quality has no significant effect on customers patronage.

TABLE 3: RESULT OF REGRESSION ANALYSIS

\begin{tabular}{|c|c|c|c|c|c|c|c|}
\hline \multirow[t]{2}{*}{ Model } & \multicolumn{2}{|c|}{$\begin{array}{l}\text { Unstandardized } \\
\text { Coefficients }\end{array}$} & $\begin{array}{l}\text { Standardized } \\
\text { Coefficients }\end{array}$ & \multirow[t]{3}{*}{$R^{2}$} & \multirow[t]{3}{*}{$\begin{array}{l}\text { Adjusted } \\
\mathrm{R}^{2}\end{array}$} & \multirow[t]{2}{*}{$\mathrm{t}$} & \multirow[t]{2}{*}{ Sig. } \\
\hline & B & Std. Error & Beta $(\mathrm{R})$ & & & & \\
\hline \multirow{2}{*}{$\begin{array}{l}\text { (Constant) } \\
\text { Service } \\
\text { Quality }\end{array}$} & 5.421 & .823 & & & & 9.933 & .000 \\
\hline & .378 & .071 & .362 & .623 & .618 & 4.863 & .000 \\
\hline
\end{tabular}

Source: Authors' computation on SPSS (2021) 


\section{Interpretation}

The result of the hypothesis in table 3 has $0.362(36 \%)$ value for beta coefficient, which reveals that service quality has an effect on customers patronage. The analysis also revealed $\left(R^{2}=0.623\right.$, Adjusted $R^{2}=0.618, P=0.000$ ) respectively. These indicates that of the variation in customers patronage, service quality accounted for $62 \%$. This is a clear indication that service quality has a significant effect on customer patronage. The independent variable has a slope coefficient of 0.378 , t-statistic of 4.863 and probability value 0.000 . The positive sign of the coefficient indicates that service quality has a positive effect on customer patronage while the $p$-value 0.000 indicates that the coefficient is statistically significant. Therefore, the null hypothesis $\left(\mathrm{H}_{0}\right)$ which state that there is no significant effect of service quality on customer patronage is hereby rejected and the alternative accepted.

\section{Hypothesis Three:}

$\mathrm{H}_{0}$ : Customer relationship management has no significant effect on customer patronage.

TABLE 4. RESULT OF REGRESSION ANALYSIS

\begin{tabular}{|c|c|c|c|c|c|c|c|c|}
\hline \multirow{2}{*}{\multicolumn{2}{|c|}{ Model }} & \multicolumn{2}{|c|}{$\begin{array}{l}\text { Unstandardized } \\
\text { Coefficients }\end{array}$} & \multirow{2}{*}{$\begin{array}{l}\text { Standardize } \\
\text { d } \\
\text { Coefficients } \\
\text { Beta }(R)\end{array}$} & \multirow[t]{2}{*}{$\mathrm{R}^{2}$} & \multirow[t]{2}{*}{$\begin{array}{l}\text { Adjusted } \\
\mathrm{R}^{2}\end{array}$} & \multirow[t]{2}{*}{$\mathrm{T}$} & \multirow[t]{2}{*}{ Sig. } \\
\hline & & $B$ & Std. Error & & & & & \\
\hline \multirow{2}{*}{$\begin{array}{l}\text { (Constant) } \\
\text { Customer } \\
\text { Management }\end{array}$} & & 1.571 & .549 & & & & 2.865 & .005 \\
\hline & Relationship & .817 & .051 & .765 & .585 & .582 & 16.053 & .000 \\
\hline
\end{tabular}

Source: Authors' computation on SPSS (2021)

\section{Interpretation}

The result in table 4 shows that $R^{2}=0.585$, Adjusted $R^{2}=0.582 . R^{2}$ measures the percentage of variation in the dependent variable caused by variation in the independent variable. This means that $(58.5 \%)$ of the variation in customer patronage is caused by customer relationship management. The balance is accounted for by the stochastic error. Also, $58.5 \%$ is substantial enough in terms of measuring the goodness of fit of the model. This is a clear indication that customer relationship management has a significant effect on customer patronage. The independent variable has a slope coefficient of 0.817 , t-statistic of 16.053 and probability value 0.000 . The positive sign of the coefficient indicates that customer relationship management has a positive effect on customer patronage while the $p$-value $<0.05$ indicates that the coefficient is statistically significant. In summary, the results have 


\section{Abioro, M.A., Odunlami, S.A. \\ IMPLICATION OF PRODUCT BRANDING ON CUSTOMER'S PATRONAGE IN THE NIGERIAN CONSUMER \\ GOODS INDUSTRY}

indicated that the null hypothesis is rejected in favor of the alternative hypothesis that customer relationship management has a significant effect on customer patronage.

\subsection{Discussion of findings}

This study assesses the implication of product branding on customers patronage in the Nigerian consumer goods industry. Following the analysis of the results from the study, there is an indication that the more customers have a positive perception about a firm's brand, and the organisation providing a quality service vis-a-vis good customer relationship management, the more they are likely to stick to the patronage of such products. In addition, the result of this study were in line with those of other previous studies like those of (Sabir et al., 2014; Oladele et al., 2015; Borishade et al., 2015 and Olawepo \& Ibojo, 2015). For example, Sabir, et al (2014) is of the view that service quality and environment are significant determinants of customer patronage in the fast-food industry in Pakistan. Also, the study of Borishade, et al (2015) as regard the effect of branding on consumer purchasing decision. The findings of the result revealed that branding plays a significant role in the purchase decision of the customer in a food and beverages firm in Nigeria. From the above assertions therefore, one can concludes that there are varying factors that could spur patronage in individual or customer of which perception and service quality delivered is one of the essential factors. Consumers react to experiences in different ways and a good or positive experience with a product or brand in service delivery would foster their patronage.

\section{CONCLUSION}

This study investigated the implication of product branding as a strategy on customer patronage in a fast-moving consumer goods industry (FMCG) in Lagos state, Nigeria. Empirical evidence from the research work revealed that product branding and how it is perceived by a firm's customers will naturally develops a personality and a reputation for the product or business. However, the result from the study further revealed that the variables of product branding (brand perception, service quality and customer relationship management) have a positive significant effect on customer's patronage. The study concluded that product branding if properly managed can serve as an effective tool which can influence customers patronage, and also having the ability to increase the customers base and profitability of the firm. 


\section{RECOMMENDATIONS}

Based on the results of this research work, the following recommendations were made:

i. Firms should give proper consideration to issues of customer relationship management; the need to enhance the product service experience of customers so as to improve the perception of their brands in the mind of customers to foster their loyalty to the brand.

ii. Organizations should continuously be innovative with new ways and strategies to continuously remain innovative and novel ways or strategies to always provide a satisfaction derived from the brands to its clients and prospective customers.

iii. It is also recommended that organizations should adopt strategic ways or methods that would align with strategic plans so as to remain on track, reduce promotional expenses and still achieve better results.

\section{REFERENCES}

Adiele, K.C. Grend, M.D. \& Chinedu, E. A. (2015). Physical Evidence and customer patronage: An empirical study of Nigeria Banking sector. British Journal of Economics, Management \& Trade, 7(3): 188-199.

Ahmed, R.R. Parmar, V. \& Amin, M.A. (2014). Impact of product packaging on consumer's buying behaviour. European Journal of Scientific Research, 120(2): 145-156.

Akbar, M.M. \& Parvez, N. (2009). Impact of service quality, trust and customer satisfaction on customer loyalty. ABAC J., 29(1): 24-38.

Ang, L. \& Buttle, F. (2006). Customer retention management process: A quantitative study. European Journal of Marketing, 40(2): $83-99$.

Anholt, S. (2010). Definitions of place branding- working towards a resolution. Journal of Place Branding and Public Diplomacy, 6(1): 1-10.

Azjen, I. \& Fishbein, M. (2008). Scaling and testing multiplicative combinations in the expectancy-value model of attitudes. Journal of applied social psychology, 38(9): 2222-2247.

Bhandari, D. \& Sharma, A. (2009). Marketing of services. Delhi:Vrinda publications Itd.

Borishade, T.T. Ogunnaike, O.O. Favour, D.J. \& Prosper, O.M. (2015). Empirical study of packaging and its effect on consumer purchase decision in a food and beverages firm. European Journal of Business and Social Sciences, 3(11): 44-53.

Cheah, I. \& Phau, I. (2011). Attitudes towards environmentally friendly products. Marketing Intelligence and Planning, 29(5): 452-472.

Dadras, A. (2016). Impact of shapes in packaging design on consumer behaviour in the lens of Kano's attractive quality theory. International Journal of Scientific Research and Management Studies, 2(1): 78-86.

Farooq, S. Habib, S. \& Aslam, S. (2015). Influence of product packaging on consumer purchase intentions. International Journal of Economics, Commerce and Management, 3(12): 538-547. 


\section{Abioro, M.A., Odunlami, S.A. \\ IMPLICATION OF PRODUCT BRANDING ON CUSTOMER'S PATRONAGE IN THE NIGERIAN CONSUMER \\ GOODS INDUSTRY}

Farquhar, J. D. (2003). Customer retention in retail financial services: An employee perspective. International Journal of Bank Marketing, 22(2): 88 - 99.

Fornell, C. (2016). Stock returns on customer satisfaction do beat the market. Journal of marketing, 80(5): 23-41.

Gummesson, E. (2015). Innovative case study research in business and management. London: Sage.

Hossein, N. \& Fateme, R. (2013). The study of the effect of brand name on customer loyalty. European Online Journal of Natural and Social Sciences, 2(3): 1104 - 1113.

Hyosung, P. \& Bryan, H. R. (2008). Relationship building and the use of website: How fortune 500 corporations use their websites to build relationships. Public Relation Review, 43(4): $405-411$.

Kotler, P. (1996). Crisis in the arts: The marketing response. California Management review. 39(1): 2852.

Kotler, P. \& Keller, K.L. (2011). Marketing Management. 14th edn. Upper Saddle River: Pearson/Prentice Hall.

Krey, A. Moelyadi, U. Maskie, G. \& Rahayu, M. (2014). Effect of quality service on customer satisfaction and loyalty (theoretical study at banking). International Journal of Business and Management Invention, 3(10): $30-35$.

Lindberg, F. (2015). Extraordinary consumer experiences. Journal of Consumer Behaviour, 14(4): 98123.

Mahdi, A. (2017). Effect of brand factors on customer loyalty with the mediating role of brand equity. International Academic Journal of Accounting and Financial Management, 4(2): 36-46.

Mcllroy, A. \& Barnett, S. (2000). Building customer relationships: do discount cards work? Managing service quality, 10(6): 347-355.

Mohebbi, B. (2014). The art of packaging: An investigation into the role of color in packaging, marketing, and branding. International Journal of Organisational Leadership, 3(4): 92-102.

Murphy, J.M. (1990). Brand strategy, Cambridge: Director books.

Negin, M. Mona, K. R. \& Niloofar, M. (2013). An examination of the effect of brands dimensions on loyalty of industrial customers. Journal of Research and Development, 1(2): 89-102.

Nilforushan, S. \& Haeri, F.A. (2015). The effect of packaging design on customers' perception of food products'quality, value, and brand preference. (Case study: Pegah pasteurised cheese, in Isfahan city). WALIA Journal, 31(3): 127-132.

Oladele, P.O. Olowookere, B. Okolugbo, C.N. \& Adegbola, E.A. (2015). Product packaging as a predictive factor of consumer patronage of toothpaste in Ado-Ekiti, Nigeria. British Journal of Marketing Studies, 3(3): 12-28.

Olawepo, G.T. \& Ibojo, B.O. (2015). The relationship between packaging and consumers purchase intention: A case study of Nestle Nigeria product. International Business and management, 10(1): $72-81$.

Oliver, R. L. (1999). Whence consumer loyalty? A behavioral perspective on the consumer. Journal of Marketing, 63(10): 33-44.

Poon, W.C. (2008). Users adoption of e-banking services. Journal of business and Industrial Marketing, 23(1): 59-69.

Sabir, R.J. Ghafoor, O. Hafeez, I. Akhtar, N. \& Rehman, A. (2014). Factors affecting customers satisfaction in restaurants industry in Pakistan. International Review of Management and Business Research, 3(2): 869-876. 
Abioro, M.A., Odunlami, S.A.

IMPLICATION OF PRODUCT BRANDING ON CUSTOMER'S PATRONAGE IN THE NIGERIAN CONSUMER GOODS

INDUSTRY

Saha, A. Hassan, K. \& Uddin, M.S. (2014). The mediating influence of service quality and organizational oath. American Journal of Trade and Policy, 1(3): 39-48.

Singh, R. \& Khan, I.A. (2012). An approach to increase customers retention and loyalty in B2C world. International Journal of Scientific Research Publications, 2(6):1 - 5.

Zekiri, J. \& Hasani, V.V. (2015). The role and impact of the packaging effect on consumer buying behaviour. ECOFORUM, 4(1): 232-240. 